No 3981

Studia nad Autorytaryzmem i Totalitaryzmem 42, nr 1

Wrocław 2020

https://doi.org/10.19195/2300-7249.42.1.5

\author{
ŁUKASZ MACHAJ \\ ORCID: 0000-0002-7247-0138 \\ Uniwersytet Wrocławski \\ lukasz.machaj@uwr.edu.pl
}

\title{
Engaging in hate speech as grounds for enhancement of criminal punishment - Wisconsin v. Mitchell
}

\begin{abstract}
The First Amendment to the Constitution of the United States, which prohibits any abridgement of freedom of speech, must be regarded as a cornerstone of the American social and political order. The number of expressive categories placed beyond the First Amendment's protective mantle is very small. In particular, there is no hate speech exception to the free speech Constitutional clause. The article analyzes the decision of the United States' Supreme Court in the case of Wisconsin v. Mitchell. The issue at hand concerned the question of whether it is constitutionally permissible to enhance criminal punishment for bias-motivated crimes in comparison with crimes motivated by other factors. In those types of cases, the factual basis for meting out a more severe punishment is usually and necessarily provided by a criminal's expression that reveals the aforementioned bias. By considering such regulations to be constitutional, the Supreme Court created an exception regarding the First Amendment protections granted to hate speech by permitting the courts - albeit in a very narrow and specific set of circumstances - to attach negative consequences to someone's engagement in constitutionally protected expressive activity. The article critically describes the doctrinal justifications given for this conclusion by the Supreme Court, considering them to be cursory and doctrinaire. The author contends that the Mitchell decision is an example of results-oriented jurisprudence, issued with the political aim of combatting hate crimes in mind. While this objective remains a worthy one, it does not — in the author's opinion — provide a sufficient justification for reducing the scope of the First Amendment's protection of (admittedly outrageous, immoral, and shocking) expression a majority may find distasteful. While the legislative branch ought to be permitted to consider specific motives as aggravating factors in a crime (at least from the First Amendment standpoint), a penalty-enhancement should not be contingent on the question whether the accused engaged in protected expressive activity, distinguishing "silent" and "vocal" criminals. The paper utilizes descriptive and analytical methods.
\end{abstract}

Keywords: hate speech, freedom of speech, First Amendment, United States' Supreme Court, criminal law. 
With respect to the question of individual rights and freedoms, the First Amendment to the Constitution of the United States must be regarded as a cornerstone of the American social and political order. One of its provisions, in conjunction with the Fourteenth Amendment, states in clear and unequivocal terms that no governmental entity (not just the legislative branch but also the executive and the judiciary), be it on the federal, state, or local level, can make any law abridging the freedom of speech. Even in the politically polarized world of today, the firm belief in government's duty to respect freedom of expression — at least as a somewhat general principle - undoubtedly remains one of the most cherished American values, one that unifies the society torn apart in recent years by a dramatic political conflict. Quoting Cass R. Sunstein, "the First Amendment's protection of free speech and free press symbolizes the American commitment to liberty under law". ${ }^{1}$ The natural consequence of this elevated position is that, to borrow the famous phrase of Ronald Dworkin, freedom of speech is definitely a right taken seriously, ${ }^{2}$ by all branches of government, including the judiciary. This fact has two important manifestations which are relevant from this article's perspective. Firstly, the courts recognize that free speech interests are implicated by a wide array of legal issues and need to be taken into account when adjudicating a huge variety of cases even if the problem prima facie doesn't have much to do with freedom of expression, as the concept in question is commonly understood. To give just a few examples, such interests have been considered in cases involving nude dancing, ${ }^{3}$ financing of political campaigns, ${ }^{4}$ zoning laws ${ }^{5}$ or use of sound amplification devices. ${ }^{6}$ To be clear, the free speech interests have not always prevailed in those controversies (or others of apparently similarly large distance between the issue in question and freedom of expression) - but they have not been summarily dismissed either, without giving them any standing or credence. The second aspect of this "serious" approach to freedom of expression is linked to the obvious fact that the constitutional requirement of no abridgement of freedom of speech cannot be identified with a prohibition against imposing any kind of punishment/regulation/burden on speech. The Supreme Court unambiguously declared in one of its landmark rulings in this particular field that "there are certain well defined and narrowly limited classes of speech, the prevention and punishment of which have never been thought to raise any Constitutional problem". ${ }^{7}$ Most, if not all, of these exceptions are justified by a historical approach to the Constitution and law aimed at discovering their original meaning. While some

\footnotetext{
1 C.R. Sunstein, Democracy and the Problem of Free Speech, New York 1995, p. XI.

2 R. Dworkin, Biorac prawa poważnie, Warszawa 1998, p. 356 and further.

3 See e.g. Barnes v. Glen Theatre, Inc., 501 U.S. 560 (1991).

4 See e.g. Buckley v. Valeo, 424 U.S. 1 (1976).

5 See e.g. Young v. American Mini Theatres, 424 U.S. 50 (1976).

6 See e.g. Saia v. New York, 334 U.S. 558 (1948).

7 Chaplinsky v. New Hampshire, 315 U.S. 568, 571-572 (1942).
}

Studia nad Autorytaryzmem i Totalitaryzmem 42, nr 1, 2020

(C) for this edition by CNS 
of these exceptions are debatable (obscenity, ${ }^{8}$ for instance), I doubt that criminalization of true threats, ${ }^{9}$ libel ${ }^{10}$ or perjury (crimes committed, at least usually, with words) raises rational doctrinal or constitutional objections in anybody's mind. At the same time, the serious approach to freedom of speech means that such categories are few and far between and that the courts restrain themselves from recognizing new classes of expression that do not enjoy the First Amendment protection. What is even more significant is that the judiciary attempts to define these exceptions as precisely as possible; the general tendency of American jurisprudence is to continuously narrow down such definitions. ${ }^{11}$ For these two reasons - while defining "hate speech" remains a very complicated and controversial endeavor, both in theory and (especially) in application — it must be said that consistent First Amendment jurisprudence does not recognize any hate speech exception to the constitutional guarantee of freedom of speech unless the expression in question falls under a different and constitutionally relevant rubric, like a true threat, a fighting word or perhaps libel (the latter is quite unlikely). ${ }^{12}$ Therefore - absent additional circumstances - a mere "expression that abuses or degrades others on account of their [...] identity" 13 remains constitutionally protected; nobody can be prosecuted or punished for using vulgar, insulting, or racially charged epithets in a situation not involving a direct confrontation; for expressing opinions promoting discrimination of or violence against any group or its members; for glorifying genocide; for Holocaust denial; for attributing certain pejorative traits to a whole group of people, identified on the basis of race, sex, gender, religion, orientation etc.; for propagating totalitarian doctrines or systems. This is a distinctive feature of the American approach to freedom of speech, making it unique in comparison with other systems.

The case we are going to discuss in this article involved a very interesting wrinkle with respect to the above-mentioned issues. Yes, the First Amendment "provides a shield for many forms of racial subordination that occur through

${ }^{8}$ See e.g. Miller v. California, 413 U.S. 15 (1973).

9 See e.g. Watts v. United States, 394 U.S. 705 (1969).

10 See e.g. New York Times Co., v. Sullivan, 376 U.S. 254 (1964).

11 For instance, regarding incitement compare Schenck v. United States, 249 U.S. 47 (1919) with Brandenburg v. Ohio, 395 U.S. 444 (1969); regarding so-called fighting words compare Chaplinsky with Cohen v. California, 403 U.S. 15 (1971) or Rosenfeld v. New Jersey, 408 U.S. 901 (1972).

12 There is one decision of the Supreme Court that seems to suggest otherwise, see Beauharnais v. Illinois, 343 U.S. 250 (1952), which upheld the penalization of "group libel". While this decision has not been formally reversed, it remains a doctrinal aberration and goes against the whole corpus of the Court's subsequent jurisprudence. See for example R.A.V. v. St. Paul, 505 U.S. 377 (1992).

13 S.J. Heyman, Hate speech and the theory of free expression, [in:] Hate Speech and the Constitution, vol. 1. The Development of the Hate Speech Debate from Group Libel to Campus Speech Codes, ed. S.J. Heyman, New York 1995, p. IX.

Studia nad Autorytaryzmem i Totalitaryzmem 42, nr 1, 2020

(C) for this edition by CNS 
racist speech and expression"14 — but what if such an expression is accompanied by a violent action? Is it constitutional that engagement in protected speech may actually deteriorate a criminal's legal situation, ultimately causing them legal harm by means of a harsher punishment? That was the essence of the issue analyzed by the Supreme Court in Wisconsin v. Mitchell. ${ }^{15}$ The facts of the case were pretty straightforward. On October 7th, 1989, a group of young African American men met and discussed "Mississippi burning". ${ }^{16}$ Afterward at the clear instigation of Mitchell (who said things like "Do you all feel hyped up to move on some white people?" or "You all want to fuck somebody up? There goes a white boy; go get him"), the group — not including Mitchell — assaulted and robbed a young boy, who, as a result of his injuries, lost consciousness and remained in a coma for a few days. The case did not pose any evidentiary difficulties and Mitchell was convicted of aggravated battery. The legal problem considered by the Supreme Court instead revolved around the fact that his sentence was drastically increased (from a maximum of two to four years ${ }^{17}$ ) in accordance with the state's penalty-enhancement scheme which raised the maximum penalty for aggravated battery to seven years in case the defendant "intentionally selects the person against whom the crime... is committed... because of the race, religion, color, disability, sexual orientation, national origin, or ancestry of that person". ${ }^{18}$ After the defendant had appealed against the conviction, his case found its way to the Wisconsin Supreme Court which reversed the lower court's ruling. The former argued that the penalty-enhancement clause violated the First Amendment because it was directed at "pure thought" or a "purely intellectual exercise" of bigotry (manifesting itself in the selection of the victim), evidenced by the expression of racially-motivated prejudices and beliefs, and because, due to having a potentially chilling effect on a constitutionally protected speech, it suffered the fatal flaw of being overbroad. ${ }^{19}$ The case eventually ended up before the Supreme

14 A.N. Ancheta, Race, Rights, and the Asian American Experience, New Brunswick 2006, p. 52 .

15508 U.S. 476 (1993).

16 For those unfamiliar with the movie, it certainly is pertinent that its action takes place in the Deep South in the 1960s, that it is centered around the murders of three civil rights workers and that the picture shows "American audiences the bone-rattling, visceral hatred and violence perpetrated by white southern Americans against black Americans", J. Roman, Bigger than Blockbusters: Movies that Defined America, Westport 2009, p. 274.

17 Regardless of the question of the constitutionality of the penalty-enhancement scheme, some scholars considered this sentence to be draconian and disproportional to the crime on its own merits, see e.g. E. Bleich, The Freedom to Be Racist? How the United States and Europe Struggle to Preserve Freedom and Combat Racism, New York 2011, p. 151.

18 Quoted in Wisconsin v. Mitchell..., 480-481.

19 I. Loveland, A Special Relationship? American Influences on Public Law in the UK, Oxford 1995 , p. 271. The overbreadth doctrine is based on the assumption that a law purporting to target a constitutionally protected expression is unconstitutional on its face even if it has some legitimate applications, see G.R. Stone et al., The First Amendment, Gaithersburg-New York 1999,

Studia nad Autorytaryzmem i Totalitaryzmem 42, nr 1, 2020

(C) for this edition by CNS 
Court which unanimously reversed the above-mentioned decision. The opinion was written by CJ William H. Rehnquist (not known for his affection towards the First Amendment ${ }^{20}$ ).

Any serious analysis of the Supreme Court's decision must necessarily commence with an inquiry into the question of whether the First Amendment is in any way implicated by both the Wisconsin law and the facts of the case. The best way to approach this issue seems to be, in my opinion, considering the nature of Mitchell's behavior (can be it defined as "speech" in the constitutional sense or is the First Amendment irrelevant?) and pinpointing this component of his activity that triggered the penalty-enhancement clause. It is especially pertinent because of the ambiguous nature of the law in question; the interpretive differences between commenting experts on the subject are surprisingly deep. For some, the Wisconsin law is simply directed at proscribable conduct of battery, not at thoughts and beliefs that motivate such action, and the penalty-enhancement is justified by greater societal harms resulting from bias-motivated crimes in comparison with ones where such a circumstance is absent; ${ }^{21}$ for others it casts racial (and other) bias "as motive rather than as thought, opinion, belief, or speech" and permissibly treats such a motive as an aggravating factor; ${ }^{22}$ others believe that the penalty enhancement is directed at "beliefs and perceptions" of a perpetrator, targeting his or her political/ideological views. ${ }^{23}$ Another interesting theory put forward by Frederick M. Lawrence is that the Wisconsin statute does not turn on motive at all but only punishes the act of discriminatory selection of a victim; Mitchell's punishment is not enhanced due to the racist motive of battery he committed or due to the viewpoint underpinning his selection of the victim but rather because he possessed a requisite mens rea, i.e. "discriminatory or animus-driven intent as to" the choice of the victim which constitutes "an aggravated form" of the crime of battery. ${ }^{24}$ As we can see, the Wisconsin law was alternatively viewed as targeting Mitchell's words, thoughts, convictions, intentions, motive, or conduct - hence the clear need for basic clarification on the part of the Supreme Court; obviously the perspective taken in this regard would influence First Amendment considerations.

Unfortunately the Chief Justice skirted the issue (to put it mildly). The decision appears to be internally inconsistent or even self-contradictory. On the one

p. 109. An example of such a law is a rule stating "No person may expressly advocate criminal conduct", ibidem, p. 114.

20 Compare S.J. Engelken, Majoritarian democracy and the Federalist system: The late Chief Justice Rehnquist and the first amendment, "Harvard Journal of Law \& Public Policy" 2007, spring, passim.

21 R.J.R. Levesque, Not by Faith Alone: Religion, Law and Adolescence, New York 2002, p. 174.

22 E. Bleich, op. cit., p. 118.

23 J.J. Jacobs, K. Potter, Hate Crimes: Criminal Law \& Identity Politics, Oxford 2001, p. 112.

24 F.M. Lawrence, Punishing Hate: Bias Crimes under American Law, Cambridge 2002, pp. 33-34.

Studia nad Autorytaryzmem i Totalitaryzmem 42, nr 1, 2020

(C) for this edition by CNS 
hand, Rehnquist contended that the law in question "is aimed at the conduct unprotected by the First Amendment" (battery) in the form reasonably deemed more dangerous than its equivalent which is not bias-motivated; the additional harms include increased potential for provoking retaliatory crimes, infliction of "distinct emotional" injuries on the victims and the peril of inciting social unrest. ${ }^{25}$ In support of this contention, Rehnquist quoted two Supreme Court's decisions which clearly excluded a violent activity from the First Amendment's protection. ${ }^{26}$ On their own, those statements would seem to solve the freedom of expression issue pretty definitively. If the Wisconsin law is aimed at conduct, not at speech, then logically it can pose no First Amendment dilemmas and all such scrutiny should cease at this point. On the other hand, however, the Court declared that because the statute "enhances the maximum penalty for conduct motivated by a discriminatory point of view more severely than the same conduct engaged in for some other reason or for no reason at all", it effectively criminalizes "the defendant's discriminatory motive" which potentially might implicate the First Amendment. ${ }^{27}$ Rehnquist seemed to try to have it both ways whereas, in my opinion, the problem should be viewed dichotomously - either the law targets an activity that is not entitled to constitutional guarantees or it targets a motive, formed by specific beliefs and (in case of Mitchell) expressed with specific words, which would necessitate a careful scrutiny of law from the First Amendment perspective. Answering this question is impossible without analyzing which part of Mitchell's behavior triggered the penalty-enhancement clause; and, in turn, this cannot be accomplished without a phenomenological inquiry with respect to the status of his activity in terms of it being in any sense "speech" as understood in the context of the First Amendment. The Court did not do that at all. At any rate, Rehnquist perceived no constitutional objection to taking discriminatory victim selection into account when the severity of a sentence was being considered, either via enhancement clauses or during the sentencing phase. While any abstract beliefs (even repugnant ones) cannot in themselves be considered an aggravating factor in any crime, the situation changes when those convictions constitute a motive for criminal activity. According to Rehnquist, the government remains absolutely within its traditional rights with respect to "fixing criminal penalties" when it makes a determination that "bias-motivated offenses warrant greater maximum

25 Wisconsin v. Mitchell..., 487, 488.

26 NAACP v. Claiborne Hardware Co., 458 U.S. 886, 916 (1982) ("The First Amendment does not protect violence"); Roberts v. United States Jaycees, 468 U.S. 609, 627-628 (1984) ("Violence or other types of potentially expressive activities that produce special harms distinct from its communicative impact [...] are entitled to no constitutional protection"). Rehnquist also invoked another famous dictum from the Supreme Court's jurisprudence, refusing to accept the position "that an apparently limitless variety of conduct can be labeled "speech" whenever the person engaging in the conduct intends thereby to express an idea", United States v. O'Brien, 391 U.S. 367, 376 (1968).

27 Wisconsin v. Mitchell..., 484-485.

Studia nad Autorytaryzmem i Totalitaryzmem 42, nr 1, 2020

(C) for this edition by CNS 
penalties across the board", as "the State's desire to redress [...] perceived harms provides an adequate explanation for its penalty-enhancement provision over and above mere disagreement with offenders' beliefs or biases". ${ }^{28}$ The Court also did not find any First Amendment problem with using the defendant's speech as evidence in terms of proving racial bias and rejected the overbreadth challenge for being "too speculative". 29

I think that Mitchell is a badly-written decision (though not necessarily — as I will try to demonstrate later - with an incorrect result), replete with conflicting statements, a very cursory reasoning and oversimplifications concerning both the nature of the law and speech arguments of the defendant. In my opinion, the Court wanted to reach a specific conclusion regarding the constitutionality of hate crime laws and it did not matter much to Justices how they got there, which makes the decision a clear example of result-based jurisprudence. ${ }^{30}$ Nevertheless, there are two components of Mitchell that are fully consistent with well-established Supreme Court precedents with respect to the First Amendment. First of all, Rehnquist attempted to maintain the distinction between laws targeting "hate speech" and "hate crimes". ${ }^{31}$ As Jeannine Bell puts it, "the Court did not intend to allow jurisdictions to criminalize pure hate speech", understood as an expression that is not directly linked to proscribable non-expressive conduct. Therefore, the government remains constitutionally permitted to "punish discriminatory conduct but may not single out hate speech for punishment". ${ }^{32}$ In other words, the decision did not carve out any new "hate speech" exception as far as the First Amendment's protection of expressive freedom is concerned. The decision confirmed that laws limiting hate speech and targeting hate crime will be subject to separate

28 Ibidem, 486-488.

29 Rehnquist contended that, in order to strike down the law on the basis of the overbreadth challenge, the Court "must conjure up a vision of a Wisconsin citizen suppressing his unpopular bigoted opinions for fear that, if he later commits an offense covered by the statute, these opinions will be offered at trial to establish that he selected his victim on account of the victim's protected status, thus qualifying him for penalty-enhancement [...] This is simply too speculative a hypothesis to support Mitchell's overbreadth claim" (Wisconsin v. Mitchell..., 488-489). I believe that it would be exceedingly difficult to question the Court's logic on that point. The overbreadth claim falls because it's a "strong medicine" that has been sparingly used by the Court, and only with respect to far more likely circumstances, see R.A. Micacci, Wisconsin v. Mitchell: Punishable conduct v. protected thought, "New England Journal on Criminal and Civil Confinement" 21, 1995, p. 157.

30 Marta Minow speculates that "it is not beyond imagination that a primarily white Court could [...] identify with a white victim" which may have directly contributed to the approach adopted in the decision, Breaking the Cycles of Hatred: Memory, Law and Repair, Princeton 2002, p. 40. For what it's worth, I doubt that the race of Mitchell's and his victim played a significant role in the Court's reasoning; if anything, if the racial "situation" had been reversed, the Court would have had even fewer problems with legitimizing the hate crime bill.

31 S. Walker, Hate Speech: The History of American Controversy, Lincoln 1996, p. 9.

32 J. Bell, Policing Hatred: Law Enforcement, Civil Rights, and Hate Crime, New York 2002, p. 19.

Studia nad Autorytaryzmem i Totalitaryzmem 42, nr 1, 2020

(C) for this edition by CNS 
standards of judicial review. According to Martha T. Zingo, "the aim ascribed to the regulation by the Court - whether it views the law as being directed primarily at speech or at conduct" will conclusively determine "the focal lens it utilizes for weighing the degree to which the law infringes the First Amendment rights of the defendant". If the law is deemed to target hate speech - the protective mantle of the First Amendment will be given an expansive interpretation; if the law is considered to be targeting "behavior arising from bias-motivated beliefs", the reading of the free speech close will be much narrower. ${ }^{33}$ Regardless of whether one agrees - from a political or ideological standpoint — with the inclusion of hate speech within the realm of constitutionally protected expression, this aspect of the Court's decision fits the basic principles verbalized in its fundamental pronouncements regarding free speech. ${ }^{34}$

The second conclusion that can be drawn from Mitchell is that penalty enhancement for biased motivation raises no First Amendment objections if freedom of expression - in the strict sense of the phrase - is not involved. In other words, if the motive for the victim's selection is not "externally" revealed by protected speech on part of the defendant, the government remains within its rights to increase the criminal punishment. Some commentators stipulated that since "freedom of speech presupposes freedom of thought", legislating the state of mind of a criminal constitutes the violation of the First Amendment in itself. ${ }^{35}$ The Supreme Court unambiguously rejected such an interpretation. In my opinion, it was the correct approach - if for no other reason, then simply because the Wisconsin law did not abridge freedom of pure thought (such attempts fortunately remain beyond the scope of governmental powers due to technological limitations, at least as things stand today) but imposed additional sanctions only for thoughts that manifested themselves in physical reality by the selection of the victim and ultimately by the criminal act itself. More importantly, taking that interpretive route would necessarily mean that any type of penalty enhancement due to an offender's motive (like profit, obsession etc.) would violate the First Amendment — and that result would definitely negate the centuries of consistent American jurisprudence. Therefore, if - hypothetically — Mitchell's racial bias

33 M.T. Zingo, Sex/Gender Outsiders, Hate Speech, and Freedom of Expression: Can They Say that About Me?, Westport 1998, p. 164.

34 See for instance West Virginia State Board of Education v. Barnette, 319 U.S. 624, 642 (1942) ("If there is any fixed star in our constitutional constellation, it is that no official, high or petty, can prescribe what shall be orthodox in politics, nationalism, religion, or other matters of opinion"); Police Department of Chicago v. Mosley, 408 U.S. 92, 95 (1972) ("The First Amendment means that government has no power to restrict expression because of its message, its ideas, its subject matter, or its content"); Texas v. Johnson, 491 U.S. 397, 414 (1989) ("If there is a bedrock principle underlying the First Amendment, it is that the government may not prohibit the expression of an idea simply because society finds the idea itself offensive or disagreeable").

35 L. Adelman, P. Moorshead, Bad laws make bad cases: Hate crime laws and the Supreme Court's opinion in Wisconsin v. Mitchell, "Gonzaga Law Review" 30, 1995, p. 3 and further.

Studia nad Autorytaryzmem i Totalitaryzmem 42, nr 1, 2020

(C) for this edition by CNS 
could have been inferred from some behavioral pattern (unlikely but theoretically possible) or if he voluntarily confessed his motive (either out of genuine remorse or because of some preferred litigation strategy), there would have been no First Amendment objection to the increased penalty. In turn, this leads to another conclusion: assuming we reject the overbreadth argument, the Wisconsin law is facially constitutional as it will have a legitimate application in a number of cases. What remains to be determined is if it is constitutional to apply it to the facts present in Mitchell's prosecution.

We can now go back to the crucial issue in this case: which aspect of Mitchell's activity triggered the penalty enhancement clause and how does it relate to the constitutional protections afforded to freedom of speech? I believe that while Mitchell's behavior was complex and can be split into distinct elements, it makes no sense to consider these elements in isolation, trying to separate conduct, thought, and expression components. Ultimately, Mitchell was pronounced guilty and sentenced for the conduct of battery committed out of a racist motive manifesting itself by his selection of the victim and by his words. In other words, the activity was complex and ought to be treated holistically; ergo one should not excise or amputate any of its constituent elements when considering the nature and constitutional ramifications of Mitchell's crime. ${ }^{36}$ It is particularly pertinent as far as the expressive component is concerned, as the significance of speech in the context of the crime committed by Mitchell (analyzed in its totality) goes beyond a mere evidentiary aspect. At the very least the words serve as a proxy for the motive; moreover, in practical terms their existence constituted a necessary condition for a successful conviction. Taking into account the concrete circumstances of this case, it seems obvious that "to eliminate speech from the prosecution is to eliminate motive",; the absence of the former would entail — by default - the impossibility of ascribing bias to Mitchell. From this perspective, the penalty enhancement clause did not really distinguish crimes motivated by bias and motivated by other factors but rather between crimes wherein bias had been openly expressed and those wherein a perpetrator remained silent regarding his biased reasons for committing a crime - and it is either purely doctrinaire or intellectually faulty to maintain otherwise. ${ }^{38}$ William J. Burnett explained it succinctly and correctly: "If Mitchell had committed the exact same physical acts silently and injured the boy in the exact same manner, he would have faced a maximum sentence of only two years imprisonment. Words alone permitted

36 See W.A. Nicolozakes, Wisconsin v. Mitchell: Criminal discrimination under the first amendment, "Capital University Law Review” 23, 1997, pp. 786-787.

37 A. Rosga, Bias before the law: The rearticulation of hate crimes in Wisconsin v. Mitchell, "New York University Review of Law \& Social Change" 25, 1999, p. 53.

38 It must be mentioned again that this passage refers to the facts present in Mitchell's case (and similar ones) - if no protected speech is involved, then obviously the above conclusion does not apply.

Studia nad Autorytaryzmem i Totalitaryzmem 42, nr 1, 2020

(C) for this edition by CNS 
Wisconsin to increase Mitchell's sentence to a maximum of three and one half times the maximum sentence for aggravated assault. Contrary to the Court's reasoning, Wisconsin's penalty enhancement statute is aimed at the expressive or communicative element of conduct; it punishes criminal defendants for what they have said". ${ }^{39}$ If Mitchell's external behavior included expressive elements, the obvious corollary is that the case is relevant to the First Amendment beyond the considered issue of freedom of thought. ${ }^{40}$

The next step is to consider the nature of this relevance. The First Amendment doctrine and jurisprudence recognize three types of expressive activities covered by the Constitutional guarantees regarding free speech. The original and central one is called "pure speech" - the written or spoken word plus conduct "limited in form to that necessary to convey the idea"41 (like art, music, movies, theatrical productions etc.). Obviously, Mitchell's behavior does not fit within this category. The second type of covered communicative activity is called "symbolic speech" a non-verbal but nevertheless expressive activity in a form extending beyond "pure speech" (the Supreme Court considered this issue in the context of, among others, burning the American flag, wearing a black armband, burning a cross or even nude dancing ${ }^{42}$ ). Since every human act is necessarily expressive, the Supreme Court needed to establish a standard for determining if such conduct is communicative enough to warrant the First Amendment protection, deciding that it 1) has to be intended to convey a "particularized message" 2) which in great likelihood will be understood by the viewers (taking into account the totality of the surrounding circumstances). ${ }^{43}$ For obvious reasons, Mitchell's activity does not fit within this framework either: not only does it include a verbal component but in general an act of battery certainly fails the second prong of the Spence test (the observers are certainly incapable of divining any communicative aspect of such an action based merely upon witnessing the act in question), and probably the second one as well (assuming that an act of battery conveys a message, it is not particularized enough to merit the First Amendment considerations). The third type of covered expressive activity is called "speech plus", i.e. conduct wherein expressive (speech) and non-expressive (actions) elements coexist. Good examples of such are erecting billboards (with an expressive content), distributing leaflets, public manifestation or picketing (including verbal slogans) etc. Mitchell's behavior appears to fall

39 W.J. Burnett, Wisconsin v. Mitchell: First amendment fast-food style, "Temple Political and Civil Rights Law Review" 4, 1995, p. 398.

40 It must be stressed at this point that relevance does not necessarily imply protection.

41 Merriam-Webster's Dictionary of Law, Springfield 1996, p. 398.

42 See, for instance, Texas v. Johnson...; Tinker v. Des Moines Independent Community School District, 393 U.S. 503 (1969); Virginia v. Black, 538 U.S. 343 (2003); City of Eerie v. Pap's A.M., 529 U.S. 277 (2000).

43 Spence v. Washington, 418 U.S. 405, 410-411 (1974).

Studia nad Autorytaryzmem i Totalitaryzmem 42, nr 1, 2020

(C) for this edition by CNS 
squarely within this category which makes it First Amendment relevant and necessitates a scrutiny of the Wisconsin law from the freedom of speech standpoint.

The proper standard for assessing the constitutionality of laws regulating "speech plus" has been enunciated by the Supreme Court in $1969^{44}$. The eponymous "O'Brien test" 45 requires that the regulation: 1) "is within the constitutional power of the Government"; 2) "furthers an important or substantial governmental interest"; 3) is intended to accomplish an interest that "is unrelated to the suppression of free expression"; 4) only incidentally restricts freedom of speech in no greater way that "is essential to the furtherance of that interest". Except for the first prong, which constitutes a kind of a threshold inquiry regarding the competence of government or its specific branch to issue a certain kind of regulation (mostly the separation of powers question), the essence of the standard is included in the third inquiry. It distinguishes regulations aimed at non-expressive elements of conduct and laws directed at its communicative components or, in other words, discerns a constitutional difference between laws triggered by a speech or action aspect of a certain complex behavior. Let us assume that someone throws a number of leaflets from a window onto a street and that the leaflets have a virulently anti-government content. If the perpetrator is punished for littering and their behavior would have been criminalized had the leaflets been pro-government (or if they had thrown blank pieces of paper), the third prong of the O'Brien test is satisfied. If, however, they are penalized for seditious libel, it is their speech that is being targeted and the standard is not upheld. Judged from this perspective, the Wisconsin law quite clearly violates the third prong of the test as it does not impose some type of incidental burden on speech but is triggered - in Mitchell's case - by his expression. The "physical" or non-communicative part of his conduct is being punished by basic anti-battery law and the penalty-enhancement provision, though theoretically directed at bias-motivated selection of the victim, only becomes a factor because of the words Mitchell spoke. Lisa M. Stozek succinctly puts it: "In enacting hate crime laws that enhance penalties for bigoted motivation, a state is not regulating conduct despite its expressive elements, but is actually penalizing already proscribed conduct more severely because of its expressive elements". 46 The law fails the O'Brien test and that conclusion should have been openly and unequivocally expressed by the Supreme Court.

However, the inability of a law to adhere to principles set forth in the O'Brien standard does not necessarily predetermine the regulation's unconstitutionality (as applied to symbolic speech). The Wisconsin law should have been assessed from the standpoint of general rules that are applicable to all types of expression. There

44 United States v. O’Brien, 391 U.S. 367 (1969).

45 Ibidem, 377. It is worth mentioning that the test is also applicable in "symbolic speech" cases.

${ }^{46}$ L.M. Stozek, Wisconsin v. Mitchell: The end of hate crimes or just the end of the first amendment?, "Northern Illinois University Law Review” 14, 1994, pp. 875-876.

Studia nad Autorytaryzmem i Totalitaryzmem 42, nr 1, 2020

(C) for this edition by CNS 
are at least two ways in which it could have been potentially saved ${ }^{47}$ The first one involves evaluating the penalty-enhancement scheme in terms of the so-called "strict scrutiny" standard. In order to pass the test, a law must 1) be justified by a compelling governmental interest, and 2) be narrowly tailored to accomplish that interest. ${ }^{48}$ To be sure, this constitutional obstacle is extremely difficult to clear; most laws subjected to it fail the second criterion because of either their overly broad sweep or the lack of correspondence between justifiable goals and used means. To legitimize the Wisconsin law on that basis would, therefore, constitute a departure from the settled jurisprudence (a minor one, but still). At the same time I would argue that a reasonable argument can be made in favor of such modification. The penalty-enhancement provision does not involve punishing anyone for engaging in hate speech as such; as long as the perpetrator's conduct does not involve other criminal acts of a physical nature, he or she remains free from the threat of prosecution and conviction. It also does not criminalize hate speech if the nexus between it and the subsequent or simultaneous crime is tentative and it cannot be proven that biased motives played a decisive role in the victim's selection. It is also worth pointing out that the Wisconsin law is somewhat overinclusive in its reach. It is entirely possible to imagine a host of different circumstances - and not purely theoretical ones either - in which a victim is selected specifically because of their "race, religion, color, disability, sexual orientation, national origin, or ancestry" but where no underlying bias or hate can be detected. A victim may be chosen on the basis of his disability because he poses an easy target and there is no risk of retaliatory action; a victim may be chosen on the basis of his or her race because the offender - correctly or mistakenly, but genuinely — believes that crimes against racial minorities are not investigated by police as diligently as those against members of a racial majority; a victim may be chosen on the basis of his sexual orientation because under specific circumstances he may be unlikely to even report a crime. While such inquiries are not usually a directly pertinent part of the "strict scrutiny" analysis, they nevertheless make it more likely that the law's intended purpose was not to penalize hate speech (or hate as such) but rather to combat specific types of criminal activities - and that therefore they do not threaten the constitutional right of engaging in hateful expression. While this avenue holds a certain allure, we are still left with the problem that in Mitchell's

47 James A. Weinstein suggested creating a new test of constitutional scrutiny for hate crime laws, pithily called "rationality with bite". In light of his proposal, a law, in order to pass muster, must have justifications which "have a substantial basis in actuality, not merely conjecture". In his opinion, the regulation in question could have passed such a test due to the very real existence of special harms connected to bias-motivated crimes; idem, Hate crime and punishment: A Comment on Wisconsin v. Mitchell, "Oregon Law Review" 73, 1994, pp. 355-357. Regardless of the merits of such assessment, I am fundamentally opposed to the judicial branch creating new ad hoc standards for constitutional adjudication. There is already quite enough of them; adding more only causes more confusion, reduces law's predictability and disproportionally increases judicial fiat.

48 S.L. Emanuel, Constitutional Law, Larchmont 2000, p. 427.

Studia nad Autorytaryzmem i Totalitaryzmem 42, nr 1, 2020

(C) for this edition by CNS 
case it was his speech (and not his motives) that practically made the crucial difference in terms of the punishment he received. Therefore the second option appears to be more promising. It would involve verifying if Mitchell's expression could be characterized as falling within one of the categories of speech deemed unprotected by the First Amendment. ${ }^{49}$ The logic here would be that if uttering certain words on their own can constitute a basis for prosecution (or any other kind of legal opprobrium), then speaking them in conjunction or connection with some type of criminal activity allows the government to attach negative consequences - a penalty-enhancement, for instance - to a perpetrator's communicative activity. In my opinion, at least one statement formulated by Mitchell — "You all want to fuck somebody up? There goes a white boy; go get him" — clearly fits the definition of the kind of expression that can be banned without running afoul of the First Amendment, i.e. incitement to violence. ${ }^{50}$ As the landmark decision of the Supreme Court on the question requires, Mitchell's encouragement was unquestionably "directed to inciting or producing imminent lawless action" and was "likely to incite or produce such action". ${ }^{51}$ While taking this interpretive road would significantly narrow the scope of the relevant law of Wisconsin, it would likely permit penalty-enhancement in almost all clear-cut cases, which usually do not involve abstract hate speech but rather incitement, true threats, or fighting words. A possible constitutional objection might be founded on the Supreme Court's pronouncement according to which the government is not allowed to selectively regulate speech belonging to any proscribable category of expression based on content-related factors. ${ }^{52}$ Prima facie, it would seem to be the case here because the penalty-enhancement scheme is applicable only to categories of expression referencing "race, religion etc.", and not, for instance, political affiliation, musical preferences, or sports fandom. However, the above principle is not without exceptions. Since the law ultimately targets hate crime and not "pure hate speech" and anyone can potentially be a victim of such a crime (black or white; gay or heterosexual, a citizen or an immigrant), "there is no realistic possibility that official suppression of ideas is afoot". 53

Faithful and consistent adherence to the First Amendment doctrine may sometimes be a very heavy cross to bear as it forces its supporters to defend wholly unsympathetic characters or completely obnoxious expression against legal sanctions. And yet, that is the very essence of freedom of speech. Hate speech definitely

49 See S.G. Gey, What if Wisconsin v. Mitchell had involved Martin Luther King Jr? The constitutional flaws of hate crime enhancement statutes, "George Washington Law Review" 65, 1997, pp. 1051-1057.

50 A similar position is taken by J. Weinstein, Hate Speech, Pornography, and the Radical Attack on Free Speech Doctrine, Boulder 1999, p. 231.

51 Brandenburg v. Ohio..., 447.

52 See R.A.V.v. St. Paul..., 383-384.

53 Ibidem, 390.

Studia nad Autorytaryzmem i Totalitaryzmem 42, nr 1, 2020

(C) for this edition by CNS 
poses a serious societal threat and it can result in grave individual and collective harms, most likely including an increase in hate crimes (as one of the contributing factors). Mark C. Thackston's assessment that the Supreme Court in Mitchell most likely attempted to send a message "to our citizens and courts that where hate crimes are concerned, enough is enough" in the hope that penalty-enhancement schemes would serve as an efficient deterrent, ${ }^{54}$ is probably correct. However, such results-oriented jurisprudence usually leads to badly reasoned decisions which are oftentimes inconsistent with the general tendencies of the judiciary, even if the objectives a court is trying to attain remain very valuable ones. The attitudinal model of decision-making might or might not be true from the descriptive standpoint but, in my opinion, such an approach is not a good idea from the normative perspective, leading to excessive judicial activism, to destabilization of the legal system and to capricious arbitrariness of the law. It is also worth noting that the debate on the issue of hate crimes should not be centered around whether it is a serious problem that must be combatted. ${ }^{55}$ The proper inquiry should be focusing on the issue of instruments that can be used in this particular struggle; specifically, if making an omelette does require breaking a few eggs, if eliminating (or limiting) hate crime is an objective worthy of narrowing the scope of the First Amendment's free speech guarantees? To invoke another saying, I believe that the Supreme Court in Mitchell threw out the baby with the bathwater - the Wisconsin law could have stood and the penalty could have been enhanced without impinging on freedom of expression and in coherence with previous jurisprudence of the Court. Taking this into account, it is however worth reiterating that the decision upheld the general principle of extending the First Amendment's protective mantle to hate speech as such.

\section{Bibliography}

Adelman L., Moorshead P., Bad laws make bad cases: Hate crime laws and the Supreme Court's opinion in Wisconsin v. Mitchell, "Gonzaga Law Review” 30, 1995.

Ancheta A.N., Race, Rights, and the Asian American Experience, New Brunswick 2006.

Barnes v. Glen Theatre, Inc., 501 U.S. 560 (1991).

Beauharnais v. Illinois, 343 U.S. 250 (1952).

Bell J., Policing Hatred: Law Enforcement, Civil Rights, and Hate Crime, New York 2002.

Bleich E., The Freedom to Be Racist? How the United States and Europe Struggle to Preserve Freedom and Combat Racism, New York 2011.

Brandenburg v. Ohio, 395 U.S. 444 (1969).

Buckley v. Valeo, 424 U.S. 1 (1976).

54 M.C. Thackston, Wisconsin v. Mitchell, "Race and Ethnic Ancestry Law Digest" 1, 1993, p. 67.

55 "Proponents' arguments in favor of hate crime laws frequently consist largely of recitations of the seriousness of the problem of bias-related crime [...] [it] does not advance the discussion because we are not disagreeing on the problem, just on the solution", S. Gellman, Hate crimes laws after Wisconsin v. Mitchell, "Ohio Northern University Law Review” 21, 1995, p. 863.

Studia nad Autorytaryzmem i Totalitaryzmem 42, nr 1, 2020

(C) for this edition by CNS 
Burnett W.J., Wisconsin v. Mitchell: First amendment fast-food style, "Temple Political and Civil Rights Law Review" 4, 1995.

Chaplinsky v. New Hampshire, 315 U.S. 568 (1942).

City of Eerie v. Pap's A.M., 529 U.S. 277 (2000).

Cohen v. California, 403 U.S. 15 (1971).

Dworkin R., Biorac prawa poważnie, Warszawa 1998.

Emanuel S.L., Constitutional Law, Larchmont 2000.

Engelken S.J., Majoritarian democracy and the Federalist system: The late Chief Justice Rehnquist and the first amendment, "Harvard Journal of Law \& Public Policy" 2007, spring.

Gellman S., Hate crimes laws after Wisconsin v. Mitchell, "Ohio Northern University Law Review" 21, 1995.

Gey S.G., What if Wisconsin v. Mitchell had involved Martin Luther King Jr? The constitutional flaws of hate crime enhancement statutes, "George Washington Law Review" 65, 1997.

Heyman S.J., Hate speech and the theory of free expression, [in:] Hate Speech and the Constitution, vol. 1. The Development of the Hate Speech Debate from Group Libel to Campus Speech Codes, ed. S.J. Heyman, New York 1995.

Jacobs J.J., Potter K., Hate Crimes: Criminal Law \& Identity Politics, Oxford 2001.

Lawrence FM., Punishing Hate: Bias Crimes under American Law, Cambridge 2002.

Levesque R.J.R., Not by Faith Alone: Religion, Law and Adolescence, New York 2002.

Loveland I., A Special Relationship? American Influences on Public Law in the UK, Oxford 1995.

Merriam-Webster's Dictionary of Law, Springfield 1996.

Micacci R.A., Wisconsin v. Mitchell: Punishable conduct v. protected thought, "New England Journal on Criminal and Civil Confinement" 21, 1995.

Miller v. California, 413 U.S. 15 (1973).

Minow M., Breaking the Cycles of Hatred: Memory, Law and Repair, Princeton 2002.

NAACP v. Claiborne Hardware Co., 458 U.S. 886 (1982).

New York Times Co., v. Sullivan, 376 U.S. 254 (1964).

Nicolozakes W.A., Wisconsin v. Mitchell: Criminal discrimination under the first amendment, "Capital University Law Review” 23, 1997.

Police Department of Chicago v. Mosley, 408 U.S. 92 (1972).

R.A.V. v. St. Paul, 505 U.S. 377 (1992).

Roberts v. United States Jaycees, 468 U.S. 609 (1984).

Roman J., Bigger than Blockbusters: Movies that Defined America, Westport 2009.

Rosenfeld v. New Jersey, 408 U.S. 901 (1972).

Rosga A., Bias before the law: The rearticulation of hate crimes in Wisconsin v. Mitchell, "New York University Review of Law \& Social Change" 25, 1999.

Saia v. New York, 334 U.S. 558 (1948).

Schenck v. United States, 249 U.S. 47 (1919).

Spence v. Washington, 418 U.S. 405 (1974).

Stone G.R., Seidman L.M., Sunstein C.R., Tushnet M.V., The First Amendment, Gaithersburg-New York 1999.

Stozek L.M., Wisconsin v. Mitchell: The end of hate crimes or just the end of the first amendment?, "Northern Illinois University Law Review" 14, 1994.

Sunstein C.R., Democracy and the Problem of Free Speech, New York 1995.

Texas v. Johnson, 491 U.S. 397 (1989).

Thackston M.C., Wisconsin v. Mitchell, "Race and Ethnic Ancestry Law Digest” 1, 1993.

Tinker v. Des Moines Independent Community School District, 393 U.S. 503 (1969).

United States v. O'Brien, 391 U.S. 367 (1968).

Virginia v. Black, 538 U.S. 343 (2003).

Walker S., Hate Speech: The History of American Controversy, Lincoln 1996.

Studia nad Autorytaryzmem i Totalitaryzmem 42, nr 1, 2020

(C) for this edition by CNS 
Watts v. United States, 394 U.S. 705 (1969).

Weinstein J.A., Hate crime and punishment: A comment on Wisconsin v. Mitchell, "Oregon Law Review" 73. Hate Speech, Pornography, and the Radical Attack on Free Speech Doctrine, 1999.

West Virginia State Board of Education v. Barnette, 319 U.S. 624 (1942).

Wisconsin v. Mitchell, 508 U.S. 476 (1993).

Young v. American Mini Theatres, 424 U.S. 50 (1976).

Zingo M.T., Sex/Gender Outsiders, Hate Speech, and Freedom of Expression: Can They Say that About Me?, Westport 1998. 